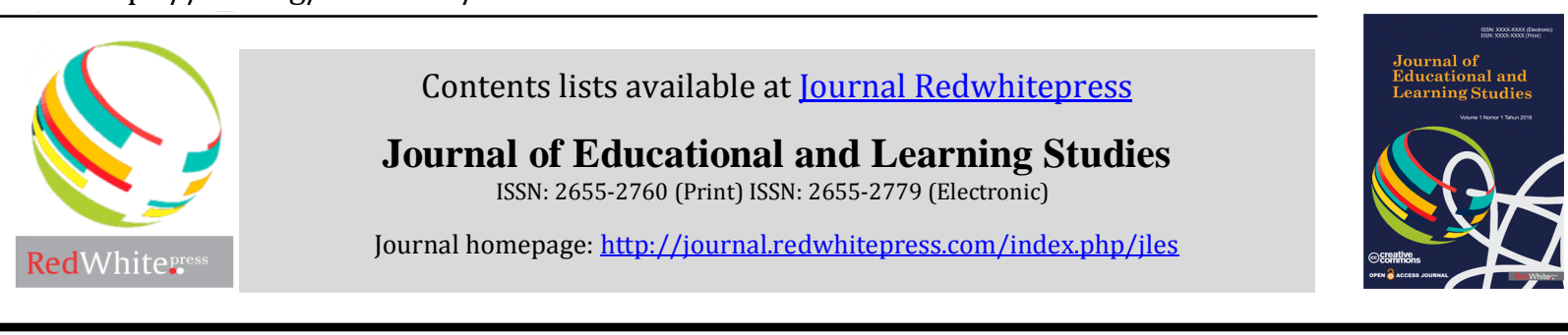

\title{
Influence analysis of instructional models and motor skills towards student achievement on sprint
}

\author{
Anggil Jufinda ${ }^{1}$, Ade Irawan ${ }^{2}$ \\ ${ }^{12}$ STKIP Muhammadiyah Sungai Penuh, Indonesia
}

\begin{tabular}{|c|}
\hline Article Info \\
\hline Article history: \\
\hline $\begin{array}{l}\text { Received May } 6^{\text {th }}, 2019 \\
\text { Revised May } 15^{\text {th }}, 2019 \\
\text { Accepted May } 26^{\text {th }}, 2019\end{array}$ \\
\hline Keyword: \\
\hline $\begin{array}{l}\text { Cooperative instructional model } \\
\text { creative play instructional } \\
\text { Motor skills fourth keyword } \\
\text { Sprint } \\
\text { Student achievement }\end{array}$ \\
\hline
\end{tabular}

Student achievement

\begin{abstract}
According to an initial observation conducted in SMPN 4 Kerinci, there were at least three biggest problems with the school: 1) absence of varied instructional models 2) lack of the students' interest in learning sprint, 3) the students' low achievements in sprint. This study aimed to analyse the influence of instructional models and motor skills towards seventh grade-student achievement on sprint at SMPN 4 Kerinci. This study employed experimental methods, with treatment by level $2 \times 2$ design. Sample of this study is 64 students who involved within two treatment groups. Results of this study showed that group of students who were taught using creative play instructional model comprehensively performed better in sprint compared to the students taught using cooperative instructional model. There was an interaction between instructional models and motor skills towards student achievement on sprint.
\end{abstract}

(C) 2019 The Authors. Published by Redwhitepress.

This is an open access article under the CC BY-NC-SA license

(https://creativecommons.org/licenses/by-nc-sa/4.0/

\section{Corresponding Author:}

Anggil Jufinda,

STKIP Muhammadiyah Sungai Penuh, Indonesia

Email: anggiljufinda@gmail.com

\section{Introduction}

Education is a deliberate effort for guidance and instructional processes of an individual to become a welldeveloped, independent, responsible, creative, healthy and well behaved human being (Indonesia, 2003). National education system of Indonesia emphasizes on its functions for skills and character development to increase welfare of the society, so that student potential could be developed to be a religious, healthy, intelligent, creative, independent, democratic and responsible individual. One of national education goals is to scaffold high qualified and physically-mentally healthy human beings. Sports education is a media to encourage motor skill development, physical skills, knowledge, intuition, morality and habituation of healthy lifestyle patterns to stimulate steady development and growth (Rahayu, 2013). Sports education is an integral part of the whole education processes aiming for physical, mental, emotional and social development through chosen physical activities to achieve targeted results (Rosdiani, 2012). Within an intense education processes in training an individual, sports education plays an important role to give chances to students in getting involved cooperatively through physical activities, plays and systematic sports. Sports education experience train and scaffold students' lifestyle to be healthier. Sports education enables students to gain validation from others, such as: fun, creative, innovative, skillful, physically 
healthy and knowledgeable about sports. (Agustina, 2018) stated that purposes of sports education are categorized into three domains:

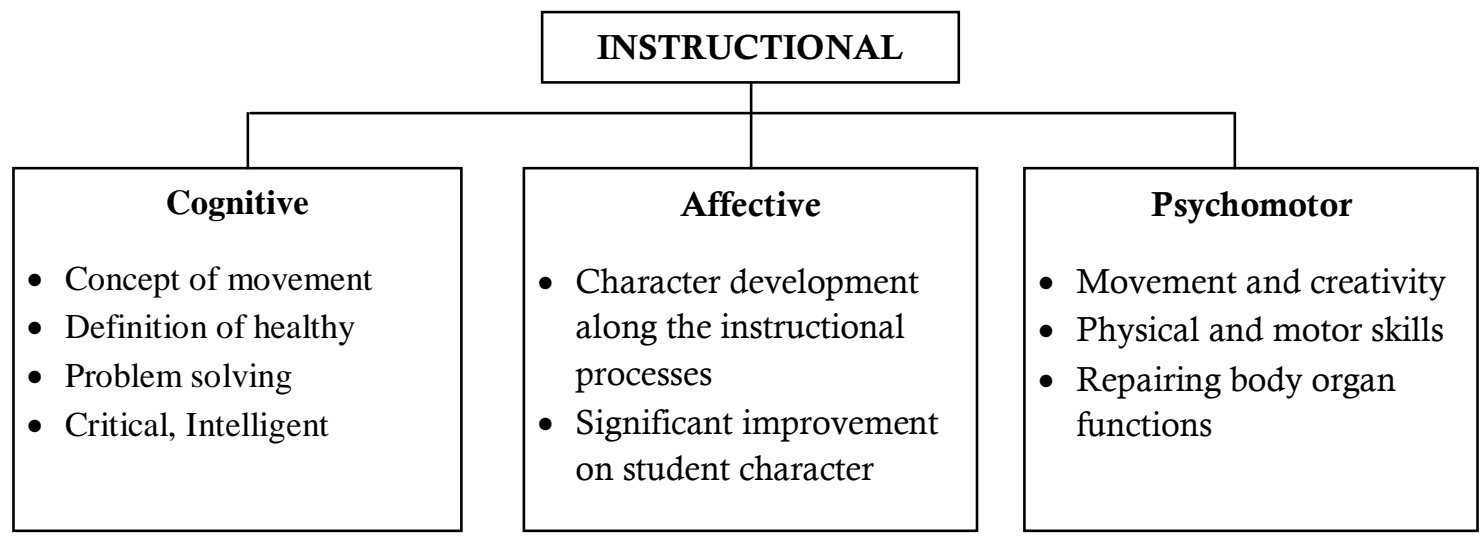

Picture 1. Sports Education Purposes

Observation conducted on sprint instructional process shows that most of the students' performance in sprint is still below passing grades set by the school. In SMPN 4 Kerinci, most of the students are not capable of doing sprint basic techniques, such as techniques when starting, running and finishing. Due to this circumstance, improvements on the school's instructional processes are significantly required through implementing instructional models and efforts to develop student motor skills. Teachers' better performance in Tutoring may also be due to the fact that they worked cooperatively make deeper connections among facts, concepts and ideas (Agoro \& Akinsola, 2013).The learning model also defines it as a conceptual process that describes complex procedures in organizing learning experiences to achieve learning goals (Suprijono, 2014).Models of teaching new is speed understanding of students in learning higher, the more creative and increased study results (Kurniadi \& Ciptono, 2015). Instructional models is a conceptual framework that describes a systematic procedure in organizing learning experiences to achieve certain learning goals and serves as a guide for learning designers and instructors in planning activities in teaching and learning (Sumanto, 2014). The increasing of students' activity in every action by applying cooperative learning (Hidayah \& Suharno, n.d.).The cooperative learning found benefits in their respective learning strategies (Kupczynski, Mundy, Goswami, \& Meling, 2012). Students' learning activeness through cooperative script method also undergoes change in the form of increase in each cycle (Damayanti, 2018). The measure of sporting student's performance for those using cooperative learning structures as a teaching base active strategy (Bensikaddour, Mokrani, Benzidane, \& Sebbane, 2015).

Basically the method chosen and used by the teacher must vary and attract the attention of the child who wants to carry out activities that have been designed by the teacher (Sujiono \& Sujiono, 2010)(Yuliani, 2010). Playing is an integral and important part of mental development and learning, and playing activities important aspects of learning and creative action play an important influence on children's physical, emotional, and social development (Flanagan, 2009)(M. Flanagan. 2009). Playing is an activity that is used to get pleasure, joy, or happiness. characteristics in play are voluntary activities, out of life habits, and pleasant. Playing is a voluntary activity characterized by minimal rules, spontaneity and fantasy, and is seen by participants as non-work (Chandler, Vamplew, \& Cronin, 2007)(T. Chandler, 2007). According to (Bee, Boyd, \& Johnson, 1998)W John (2011), Playing helps children overcome anxiety and conflicts. Because tension can be relieved through play activities, children can overcome life problems. Physical education teachers need additional skills, knowledge, and understanding needed from other lessons in the main curriculum and are able to learn from observations, as well as about safety needs in the learning process. (Hopper, Grey, \& Maude, 2005)(B. Hopper, 2005).The physical abilities of students' in order to help to further optimize the increase in the gross motor skills (Hayati, Myrnawati, \& Asmawi, 2017)(S. Hayati, 2017).Besides the obvious health related benefits, physical activities help unfolding natural development potential in students'. They get used to exploit their motor abilities in variable situations and intensities (Bensikaddour et al., 2015)(H. Bensikaddou, 2015).For students who have motor skills low, the learning outcomes of short distance runs are higher when using a model cooperative learning (Jufinda, 2019)(A. Jufinda, 2019).The implementation of cooperative model can also increase student's learning activity, both cognitively and 
Influence analysis of instructional models and motor skills towards student achievement on sprint

physically (Fidiyanti, 2017)(H. H. N. Fidiyanti, 2019).The implementations are expected to increase the students' discipline in sports and health learning processes at the school and increase learning efficacy indicated by the students' physical, mental, emotional, psychomotor and moral improvements. Therefore, researcher believes it is important to conduct a research to analyse influenes of instructional models and motor skills towards student achievement on sprint at smpn 4 kerinci.

\section{Method}

Three variables were included in this research: (1) creative play and cooperative instructional models as independent variables, (2) student sprint performance scores as dependant variables and (3) student motor skills as attribute variables. Method applied in this research were $2 \times 2$ factorial design. In this method, experimental units were grouped properly into cells so that the experimental units within cell were relatively homogeny. The amount of experimental units within cell was parallel to the amount of experimental treatments. The treatments were conducted randomly towards the experimental units within cell. $2 \times 2$ factorial design applied in this research is as followed:

Table 1. 2 x 2 Factorial Design

\begin{tabular}{ccc}
\hline instructional model (A) & $\begin{array}{c}\text { Creative Play Model } \\
\left(\mathrm{A}_{1}\right)\end{array}$ & $\begin{array}{c}\text { Cooperative Model } \\
\left(\mathrm{A}_{2}\right)\end{array}$ \\
\cline { 3 - 3 } & & \\
motor skills (B) & & $\mathrm{A}_{2} \mathrm{~B}_{1}$ \\
High motor skills $\left(\mathrm{B}_{1}\right)$ & $\mathrm{A}_{1} \mathrm{~B}_{1}$ & $\mathrm{~A}_{2} \mathrm{~B}_{2}$ \\
\hline
\end{tabular}

Description:

$\mathrm{A}_{1} \mathrm{~B}_{1} \quad$ : Group where creative play model applied for students who have high motor skills on sprint

$\mathrm{A}_{2} \mathrm{~B}_{1} \quad$ : Group where cooperative model applied for students who have high motor skills on sprint

$\mathrm{A}_{1} \mathrm{~B}_{2} \quad$ : Group where creative play model applied for students who have low motor skills on sprint

$\mathrm{A}_{2} \mathrm{~B}_{2} \quad$ : Group where cooperative model applied for students who have low motor skills on sprint

\section{Sampling techniques}

Sample is a part of amounts and characteristics of a population (Sugiyono, n.d.). Purposive sampling was applied in this study to obtain data in order to address the hypotheses. Purposive sampling is a sampling technique with particular considerations. Considerations in this study refer to the need for samples to contain students with high motor skills and those with low motor skills. Suggested ways to get students with different motor skills for the two instructional models applied in this study: First, take $27 \%$ from total scores. Second, order scores from the highest until required sample size obtained and order the scores from the lowest until required sample size obtained, the middle score between the highest and lowest score was dismissed.

Subsequently, 27\% of the scores from higher and lower area were taken which included 32 samples for each high and low motor skill samples. Thus, sample sequence including 1st-32ndrank was categorised as a group of students with high motor skills and sample sequence including 88th-120th rank was categorised as a group of students with low motor skills. Scores located in between, which ranked 33th-87th, were dismissed. Thus, the amount of students included into instructional and motor skills group was 64 students. The 64 students were then grouped into four categories: (1)A1B1 group which consists of 16 students with high motor skills on sprint, creative play model was applied for this group of students, (2) A2B1 group which consists of 16 students with high motor skills on sprint, cooperative model was applied for this group of students, (3) A1B2 group which consists of 16 students with low motor skills on sprint, creative play model was applied for this group of students, (4) A2B2 group which consists of 16 students with low motor skills on sprint, cooperative model was applied for this group of students.

\section{Data collection techniques}

According to the experimental design, there were two kind of data required in this study: (1) Data of student motor skills and (2) Data of student scores on sprint. In order to obtain the two data, tests and measurements were applied.

\section{Data analysis techniques}


The data were analyzed using one-way ANOVA test to know if there were differences in problem-solving ability among the students of the experimental class, comparative class, and control class (I. M. Suarsana, 2019). Analysis of Variance (ANOVA) was used in this study, along with $2 \times 2$ factorial design on significance rate of $\alpha=0$. 05. Prior to ANOVA application, tests on normality and homogeneity of variances were applied.

\section{Statistical hypothesis}

1) $\mathrm{H}_{0}: \mu_{\mathrm{A} 1} \leq \mu_{\mathrm{A} 2}$

$\mathrm{H}_{1}: \mu_{\mathrm{A} 1}>\mu_{\mathrm{A} 2}$

2) $\mathrm{H}_{0}:$ Int. $\mathrm{A} X \mathrm{X}=0$

$\mathrm{H}_{1}:$ Int. $\mathrm{A} X \mathrm{X} \mathrm{B} \neq 0$

3) $\mathrm{H}_{0}: \mu_{\mathrm{A} 1 \mathrm{~B} 1} \leq \mu_{\mathrm{A} 2 \mathrm{~B} 1}$

$\mathrm{H}_{1}: \mu_{\mathrm{A} 1 \mathrm{~B} 1}>\mu_{\mathrm{A} 2 \mathrm{~B} 1}$

4) $\mathrm{H}_{0}: \mu_{\mathrm{A} 1 \mathrm{~B} 2} \geq \mu_{\mathrm{A} 2 \mathrm{~B} 2}$

$\mathrm{H}_{1}: \mu_{\mathrm{A} 1 \mathrm{~B} 2}<\mu_{\mathrm{A} 2 \mathrm{~B} 2}$

Description:

$\mu_{\mathrm{A} 11} \quad$ :The average sprint score for creative play model group

$\mu_{\mathrm{A} 2} \quad$ : The average sprint score for cooperative model group

$\mu_{\mathrm{A} 1 \mathrm{~B} 1} \quad$ : The average sprint score for creative play group model with high motor skills

$\mu_{\mathrm{A} 2 \mathrm{~B} 1}:$ The average sprint score for cooperative model with high motor skills

$\mu_{\mathrm{A} 1 \mathrm{~B} 2} \quad$ : The average sprint score for creative play model with low motor skills

$\mu_{\mathrm{A} 2 \mathrm{~B} 2} \quad$ : The average sprint score for cooperative model with low motor skills

\section{Results and Discussions}

\section{Results}

Result description analyzed and delivered in this chapter describes the data, prerequisite test for analysis, hypothesis test, result discussion with the following themes: there were three variables used in this study (dependent, independent and attribute variables). The dependant variable was the students' sprint scores, the independent variable was creative play and cooperative instructional model and the attribute variable was the students' motor skills.

\section{a. Data Description}

The purpose of data description on the results was to obtain a comprehensive characteristic portrayal of sprint techniques as the subject of this study. There were four elements analyzed to examine the elements' influence on the students' sprint scores: creative play instructional model, cooperative instructional model, the students' high motor skills and the students' low motor skills. The students' sprint scores from each treatment group are described in the following table:

Table 2. Result Data Conclusion

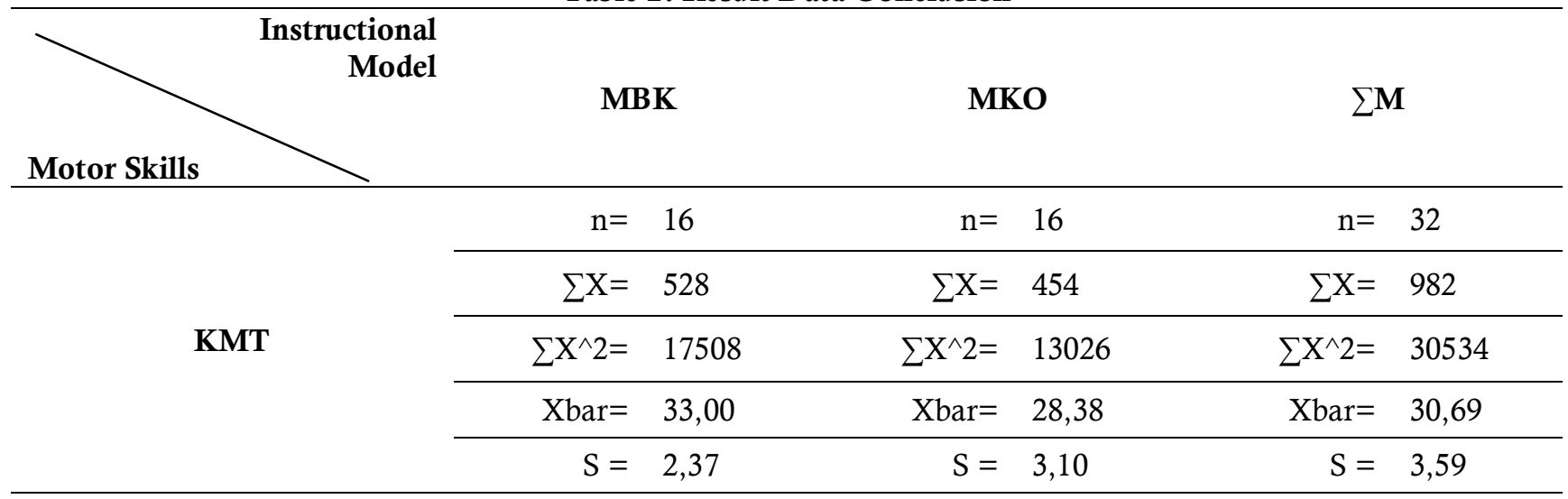


Influence analysis of instructional models and motor skills towards student achievement on sprint

\begin{tabular}{|c|c|c|c|c|c|c|}
\hline \multirow{5}{*}{ KMR } & $\mathrm{n}=$ & 16 & $\mathrm{n}=$ & 16 & $\mathrm{n}=$ & 32 \\
\hline & $\sum \mathrm{X}=$ & 430 & $\sum \mathrm{X}=$ & 442 & $\sum \mathrm{X}=$ & 872 \\
\hline & $\sum X^{\wedge} 2=$ & 11686 & $\sum X^{\wedge} 2=$ & 12330 & $\sum X^{\wedge} 2=$ & 24016 \\
\hline & Xbar= & 26,88 & Xbar $=$ & 27,63 & Xbar $=$ & 27,25 \\
\hline & $S=$ & 2,94 & $S=$ & 2,83 & $S=$ & 2,86 \\
\hline \multirow{5}{*}{$\sum \mathbf{G}$} & $\mathrm{n}=$ & 32 & $\mathrm{n}=$ & 32 & $\mathrm{n}=$ & 64 \\
\hline & $\sum \mathrm{X}=$ & 958 & $\sum \mathrm{X}=$ & 896 & $\sum \mathrm{X}=$ & 1854 \\
\hline & $\sum X^{\wedge} 2=$ & 29194 & $\sum X^{\wedge} 2=$ & 25356 & $\sum X^{\wedge} 2=$ & 54550 \\
\hline & Xbar= & 29,94 & Xbar $=$ & 28,00 & Xbar $=$ & 28,97 \\
\hline & $\mathrm{S}=$ & 2,65 & $S=$ & 2,96 & $\mathrm{~S}=$ & 2,81 \\
\hline
\end{tabular}

Description:

$\mathrm{n} \quad:$ The number of samples within each treatment group

$\sum \mathrm{x} \quad$ : The number of scores within each treatment group

$\sum x^{2} \quad$ :The square number of scores within each treatment group

$\bar{X} \quad$ : The average score of the students' sprint scores

s : Standard deviation

\section{b. The Total of Student Sprint Scores for Creative Play Group (A1)}

The total sprint scores for students who were taught with creative play model range between 37-20, with mean value 29.9 , median value 30.5 , modal value 31.0 and standard deviation 4.07 . One student (3.13\% of the total) is noted achieving a score with a range between $20-22$, five students ( $15.6 \%$ of the total) are noted achieving scores with a range between $23-35$, five students (15.6\% of the total) are noted achieving scores with a range between $26-68$, nine students $(28.13 \%$ of the total) are noted achieving scores with a range between $29-31$, seven students $(21.88 \%$ of the total) are noted achieving scores with a range between $32-24$ and five students $(15.63 \%$ of the total) are noted achieving scores with a range between 35-57.

\section{c. The Total of Student Sprint Scores for Cooperative Group $\left(\mathrm{A}_{2}\right)$}

The total sprint scores for students who were taught with cooperative model range between $34-23$, with mean value 28 , median value 28 , modal value 27 and standard deviation 2.9 . Four student (12.50\% of the total) are noted achieving scores with a range between $23-24$, six students $(18.75 \%$ of the total) are noted achieving scores with a range between $25-26$, eight students (25\% of the total) are noted achieving scores with a range between $27-28$, six students $(18.75 \%$ of the total) are noted achieving scores with a range between $29-30$, six students (18.75\% of the total) are noted achieving scores with a range between $31-32$ and two students $(6.25 \%$ of the total) are noted achieving scores with a range between 33-34.

\section{d. Student Sprint Scores for Creative Play Group with High Motor Skills (A1B1)}

The total sprint scores for students who were taught with creative play model with high motor skills range between $31-22$, with mean value 33 , median value 33 , modal value 33 and standard deviation 2.37 . Three student ( $18.75 \%$ of the total) are noted achieving scores with a range between $29-30$, three students (18.75\% of the total) are noted achieving scores with a range between $31-32$, five students $(31.25 \%$ of the total) are noted achieving scores with a range between $33-34$, five students $(31.25 \%$ of the total) are noted achieving scores with a range between 35-36. 


\section{e. Student Sprint Scores for Cooperative Group with High Motor Skills(A2B1)}

The total sprint scores for students who were taught with cooperative model with high motor skills range between $34-23$, with mean value 28.4 , median value 28.0 , modal value 27.0 and standard deviation 3.10 . Three student $(18.75 \%$ of the total) are noted achieving scores with a range between $23-25$, six students $(37.50 \%$ of the total) are noted achieving scores with a range between $26-28$, four students ( $25 \%$ of the total) are noted achieving scores with a range between $29-31$, three students (18.75\% of the total) are noted achieving scores with a range between 32-34.

\section{f. Student Sprint Scores for Creative Play Group with Low Motor Skills(A1B2)}

The total sprint scores for students who were taught with creative play model with low motor skills range between $31-22$, with mean value 26.9 , median value 27.0 , modal value 27.0 and standard deviation 2.94 . Two student (12.50\% of the total) are noted achieving scores with a range between $22-23$, four students $(25.00 \%$ of the total) are noted achieving scores with a range between $24-25$, four students $(25.00 \%$ of the total) are noted achieving scores with a range between $26-27$, two students (12.50\% of the total) are noted achieving scores with a range between $28-29$ and four students $(25.00 \%$ of the total) are noted achieving scores with a range between 30 31.

\section{g. Student Sprint Scores for Cooperative Group with Low Motor Skills(A2B2)}

The total sprint scores for students who were taught with cooperative model with low motor skills range between $32-23$, with mean value 27.6 , median value 27.5 , modal value 25.0 and standard deviation 2.83 . Two student $(12.50 \%$ of the total) are noted achieving scores with a range between $23-24$, four students $(25.00 \%$ of the total) are noted achieving scores with a range between $25-26$, three students (18.75\% of the total) are noted achieving scores with a range between $27-28$, four students $(25.00 \%$ of the total) are noted achieving scores with a range between $29-30$ and three students $(18.75 \%$ of the total) are noted achieving scores with a range between 31 32.

\section{Discussion}

Prior to ANOVA application, prerequisite tests were conducted: (1) normality test and (2) homogeneity of variance. The prerequisite test results in this study are as followed:

\section{a. Normality Test}

Normality test on scores after application of particular instructional model was conducted using liliefors test on significance rate of $\alpha=0,05, \mathrm{~L}_{\mathrm{o}}$ obtained for the whole sample group results was smaller compared to $\mathrm{L}_{\mathrm{t}}$. Thus, a conclusion could made that the samples are from normally-distributed population.

\section{b. Homogeneity Test}

Homogeneity test was conducted using Bartlett test with significance rate of $\alpha=0,05$, the value of $\mathrm{X}^{2}{ }_{\mathrm{h}}=$ 1,156 in which smaller compared to $X_{t}^{2}=7,81$ so that Ho: $\sigma^{2} 1=\sigma^{2} 2=\sigma^{2} 3=\sigma^{2} 4$ accepted with $\alpha=0,05$. Thus, a conclusion could be made that the four populations have homogenous variances.

\section{c. Hypotheses Test}

Hypotheses test using analysis of varian (anava) two stripe and Tukey Test.

Table3. Result Data Analysis Of Varian (Anava) Two Stripe

\begin{tabular}{lccccc}
\hline \multicolumn{1}{c}{ Varian Sources } & DB & JK & RK & $\mathbf{F}_{\mathbf{H}}$ & $\mathbf{F}_{\mathbf{T}}$ \\
\hline Between Lines(b) & 1 & 189,063 & 189,063 & 23,769 & 4,00 \\
\hline Between Columns(k) & 1 & 60,063 & 60,0625 & 7,551 & 4,00 \\
\hline Interaction(bxk) & 1 & 116 & 115,563 & 14,529 & 4,00 \\
\hline In & 60 & 477,25 & 7,95417 & - & - \\
\hline
\end{tabular}


Influence analysis of instructional models and motor skills towards student achievement on sprint

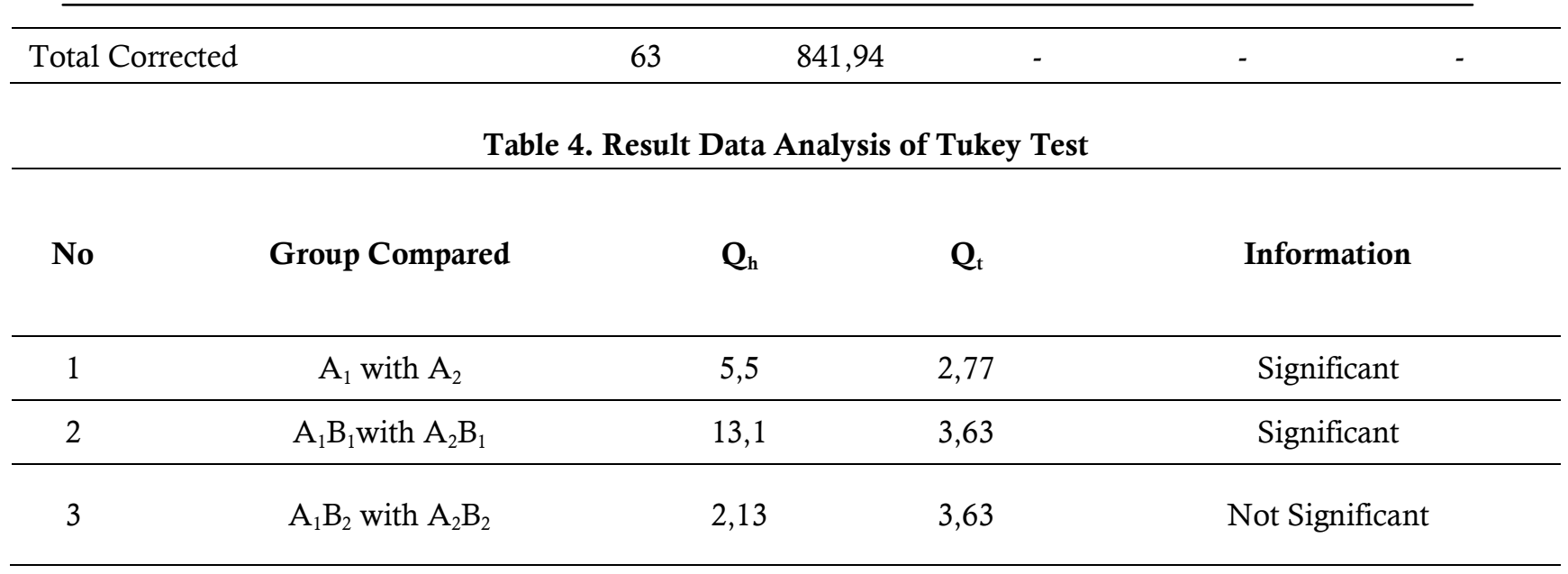

\section{Conclusion}

According to statistical data analysis and hypothesis test, this study examined four main ideas as followed: 1) Research hypotheses stating that the students taught with creative play model (A1) and cooperative model (A2), are accepted, creative play instructional model on student sprint scores theoretically is more effective compared to cooperative instructional model. Subsequent to the research implementation, the hypothesis is significantly accepted; 2) The second hypothesis research stating that there is an interaction between cooperative instructional model and motor skills on student scores in sprint, is accepted. Hypothesis conducted proved that there is an interaction between instructional models and motor skills on student sprint scores. Group of students with higher motor skills and taught by creative play model achieved higher scores in sprint compared to the students with high motor skills and taught by cooperative model. On the other hand, group of students with lower motor skills and taught by creative play model achieved lower scores in sprint compared to the students with lower motor skills and taught by cooperative model; 3) The third hypothesis stating that group of students with higher motor skills and taught by creative play model (A1B1) achieve higher scores in sprint compared to those with higher motor skills and taught by cooperative model (A2B1), is accepted. Motor skills are common capacity (potential for basic support) in technical skills (general motoric) on one particular branch of sports. Ones with higher motor skills are more skilled in doing movements. Creative play model is an instructional model which provides opportunities for students to develop movement skills in various ways in order to achieve sports education goals, particularly in sprint; 4) The fourth hypothesis shows an indication of rejection due to unsupported data. The rejected hypothesis is not relevant with theories and frameworks explained in the second chapter. Thus, further discussion on possibilities causing the hypothesis rejection is recommended. The possibilities are at least related to two aspects: (a) Limited time to learn the subject, (b) Students' motivation as a psychological factor. Motivation is supporting factor for ones to immerse in activities. Overall, creative play model is proved to positively influencing compared to cooperative model. It is recommended for students with higher motor skills to be taught using creative play model for better performance in sprint. Students with lower motor skills are more likely to perform better in sprint if they are taught by either one of the models. However, cooperative model is recommended for students with lower motor skills due to the results obtained in this research

\section{Acknowledgement}

I would like to address his gratitude to KEMENRISTEK DIKTI who have been financially supporting this research. I would also like to include a special note of thanks to the Institutional President, lecturers and stakeholders of STKIP Muhammadiyah Sungai Penuh who have been giving their supports for the completion of this research.

\section{References}


Agoro, A. A., \& Akinsola, M. K. (2013). Effectiveness Of Reflective-Reciprocal Teaching On Pre-Service Teachers' Achievement And Science Process Skills In Integrated Science. International Journal of Education and Research, 1(8), 1-20.

Agustina, N. (2018). Perkembangan peserta didik. Deepublish.

Bee, H. L., Boyd, D. R., \& Johnson, P. A. (1998). Lifespan development. Longman New York.

Bensikaddour, H., Mokrani, D., Benzidane, H., \& Sebbane, M. (2015). The importance of the practice of competitive games kid's athletics in physical education for college students (11-12 years) using the cooperative learning strategy. European Scientific Journal, ESJ, 11(32).

Chandler, T., Vamplew, W., \& Cronin, M. (2007). Sport and physical education: the key concepts. Routledge.

Damayanti, A. (2018). Implementing Cooperative Script Type of Cooperative Learning Model To Improve Students' Activeness in Learning Social Studies. International Journal Pedagogy of Social Studies, 3(1), 129-136.

Fidiyanti, H. H. N. (2017). Effect Of Implementation Of Cooperative Learning Model Make A Match Technique On Student Learning Motivation In Social Science Learning. International Journal Pedagogy of Social Studies, 2(1), 104-114.

Flanagan, M. (2009). Critical play: Radical game design. MIT press.

Hayati, H. S., Myrnawati, C. H., \& Asmawi, M. (2017). Effect of Traditional Games, Learning Motivation And Learning Style On Childhoods Gross Motor Skills. International Journal of Education and Research, 5(7).

Hidayah, N. A. W., \& Suharno, M. I. (n.d.). The use of Cooperative Learning of Jigsaw-Type and Make a Match Type to Improve Students" Activity.

Hopper, B., Grey, J., \& Maude, P. (2005). Teaching physical education in the primary school. Routledge.

Indonesia, P. R. (2003). Undang-undang Republik Indonesia nomor 20 tahun 2003 tentang sistem pendidikan nasional. Jakarta: Pemerintah Republik Indonesia.

Jufinda, A. (2019). Pengaruh model pembelajaran dan kemampuan motorik terhadap hasil belajar lari jarak pendek (Studi Eksperimen di SMP Negeri 34 Kerinci). Ensiklopedia of Journal, 1(3).

Kupczynski, L., Mundy, M. A., Goswami, J., \& Meling, V. (2012). Cooperative Learning in Distance Learning: A Mixed Methods Study. Online Submission, 5(2), 81-90.

Kurniadi, A., \& Ciptono, C. (2015). Bola Tangkup: A Media to Stimulate Gross Motor Skills' Children with Visual Impairment. Indonesian Journal Of Early Childhood Education Studies, 4(2), 86-89.

Rahayu, E. T. (2013). Strategi Pembelajaran Pendidikan Jasmani. Bandung: Alfabeta.

Rosdiani, D. (2012). Dinamika olahraga dan pengembangan nilai. Bandung: Alfabeta.

Sugiyono, P. (n.d.). Dr. 2010. Metode Penelitian Kuantitatif, Kualitatif, Dan R\&D. Bandung: CV Alfabeta.

Sujiono, Y. N., \& Sujiono, B. (2010). Bermain kreatif berbasis kecerdasan jamak. Jakarta: Indeks.

Sumanto, M. A. (2014). Psikologi Perkembangan (Fungsi dan Teori). Jakarta: CAPS.

Suprijono, A. (2014). Cooperative Learning Teori \& Paikem. Jogyakarta: Pustaka Pelajar. 